\title{
Mellkasi panasz ritka oka
}

\author{
Bodócsi Beáta dr. ${ }^{1}$ - Koncz István dr. ${ }^{1}$ - Hum Zsigmond dr. ${ }^{1}$ \\ Serfőző Orsolya dr. ${ }^{1}$ - Pap-Szekeres József dr. ${ }^{2}$ - Szabó István dr. ${ }^{1}$
}

Bács-Kiskun Megyei Kórház, 'Sürgősségi Betegellátó Osztály, ²Általános Sebészeti Osztály, Kecskemét

\begin{abstract}
A mellkasi fájdalom igen gyakori panasz a sürgősségi osztályon megjelent betegek körében. A sürgősségi orvosok fontos feladata kizárni az életet veszélyeztető kórképeket: akut coronariaszindróma, pulmonalis embolisatio, mellkasi aortadissectio. A szerzők 7 órája fennálló tompa mellkasi fájdalom miatt jelentkező beteg kórtörténetét ismertetik. A diagnosztikus algoritmusoknak megfelelően EKG, vérvétel, mellkasröntgen, majd ezek után mellkasi komputertomográfiás angiográfia történt. Az akut coronariaszindróma, pulmonalis embolisatio, valamint a mellkasi aorta dissectiója kizárásra kerültek, azonban a CT-képen mellékleletként hatalmas méretű rekeszsérv ábrázolódott. A betegnél sürgős mútét történt, amely után a beteg panaszmentesen, gyógyultan távozott a kórházból. A szerzők kiemelik, hogy a diagnosztikus algoritmusok a gyakori, potenciálisan halálos betegségek megerősítését vagy kizárását célozzák meg, elsősorban mellkasi panaszok esetén. Nem szabad azonban szem elől téveszteni, hogy a mellkasi fájdalomnak vannak ritkább okai, amelyek a társszakmák bevonását, multidiszciplináris gondolkodásmódot tesznek szükségessé. Orv. Hetil., 2016, 157(36), 1445-1448.
\end{abstract}

Kulcsszavak: mellkasi fájdalom, rekeszsérv

\section{A rare case of chest pain}

Chest pain is a common symptom in patients who visit Emergency Departments. The main task is to exclude lifethreatening diseases such as acute coronary syndrome, pulmonary embolization and dissection of thoracic aorta. The authors present the history of a patient, who had an intense chest pain for 7 hours. In accordance with the diagnostic algorithm of chest pain, ECG, blood collection, chest X-ray and chest computed tomography angiography were performed. Acute coronary syndrome, pulmonary embolization and dissection of the thoracic aorta were excluded, however, chest computed tomography CT revealed a huge hiatal hernia as an incidental finding. An emergency surgical repair was performed and the patient recovered without any complications. The authors emphasize that the diagnostic algorithms focus on the confirmation or rejection of possible life threatening diseases in case of chest pain. However, it should be kept in mind that rarer causes may occur, which may require involvement of the relevant disciplines and multidisciplinary thinking.

Keywords: chest pain, hiatal hernia

Bodócsi, B., Koncz, I., Hum, Zs., Serfözó, O., Pap-Szekeres, J., Szabó, I. [A rare case of chest pain]. Orv. Hetil., 2016, 157(36), 1445-1448.

(Beérkezett: 2016. április 24.; elfogadva: 2016. június 23.)

\section{Rövidítések}

ACS = akut coronariaszindróma; AMI = akut myocardialis infarctus; $\mathrm{CK}=$ kreatinkináz; $\mathrm{CK}-\mathrm{MB}$ = szívizom-specifikus kreatinkináz; $\mathrm{CT}$ = komputertomográfia; $\mathrm{EKG}=$ elektrokardiogram; GFR = glomerulusfiltrációs ráta; ISZB = ischaemiás szívbetegség; PE = pulmonalis embolisatio; PTX = légmell; TBC = tuberkulózis; TropI = troponin I; VAS = vizuális analóg skála

A mellkasi fájdalom az egyik leggyakoribb panasz a sürgősségi osztályra bekerülő betegek körében. Főként az akut, életet veszélyeztető kórképek - mint akut coronaria- szindróma (ACS), pulmonalis embolisatio (PE), mellkasi aorta dissectiója - kizárása az elsődleges cél. Diagnosztikus vizsgálómódszereink elsősorban ezeknek a kórképeknek a kizárását vagy megerősítését célozzák meg. Mégis előfordulhat, hogy mintegy mellékleletként észlelésre kerül olyan betegség, amely igen ritka, de potenciálisan halálos is lehet [1].

\section{Esetismertetés}

Egy 80 éves férfi beteg érkezett esetkocsival sürgősségi osztályunkra, 7 órája fennálló mellkasi panasz miatt. 

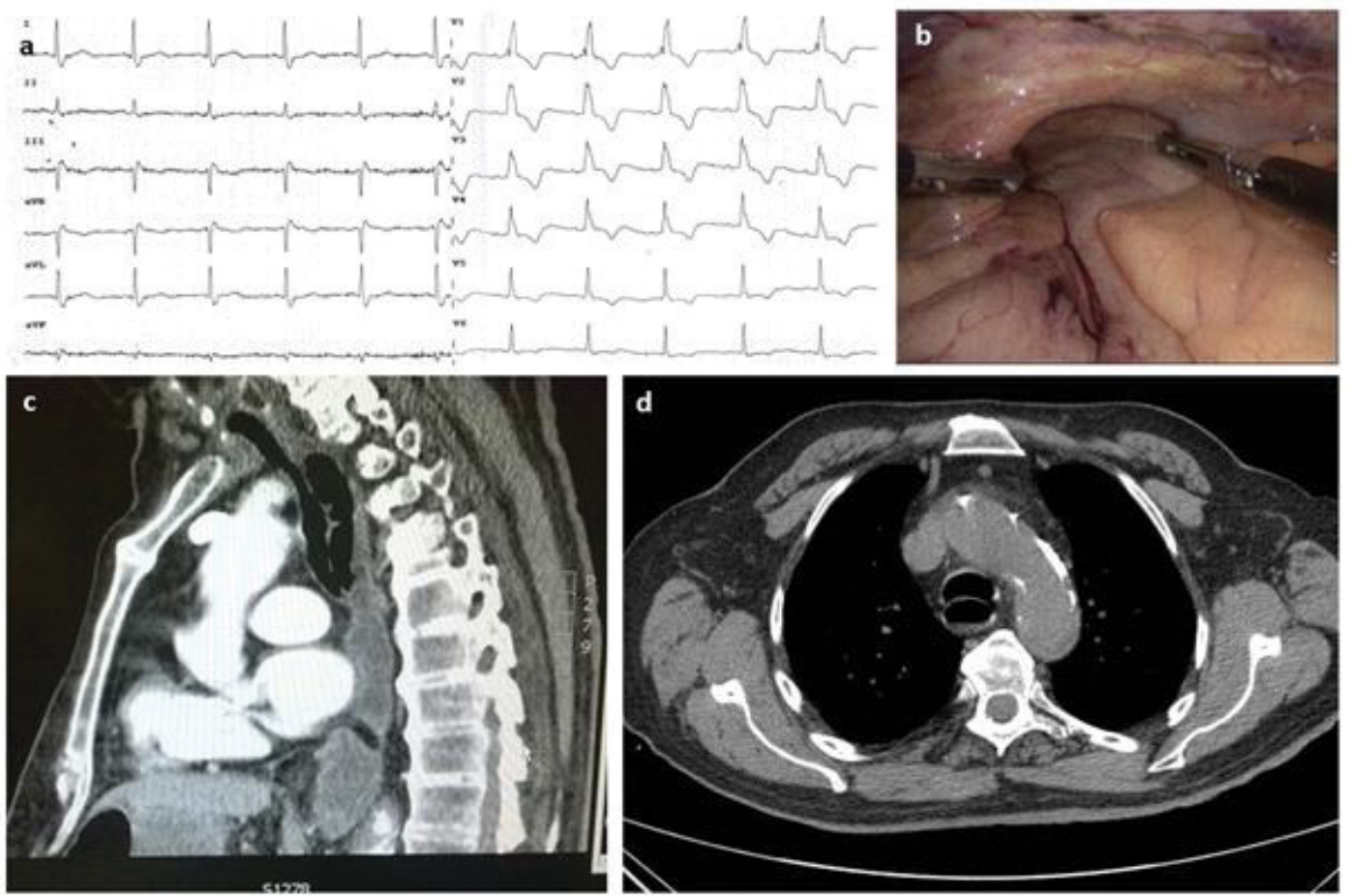

1. ábra

| Betegünk: EKG-ja (a), mútéti képe (b) és mellkasi CT-angiográfiás képe (c-d)

A fájdalom éles-szúró jellegű volt, és a mellkas középső részéból a hát irányába sugárzott ki. A fájdalom vizuális analóg skálán (VAS) körülbelül 6-os erôsségú volt, a beteg azonban gyógyszert nem vett be, korábban ilyen jellegü rosszulléte nem volt. A mellkasi panaszhoz nehézlégzés érzése is társult. Heves szívdobogásérzés, köhögés, köpetürítés, vérköpés, lábdagadás nem jelentkezett. Hasi panasz, hányinger, hányás, láz, hidegrázás, szédülés, eszméletvesztés nem voltak. A betegnek a székletével, vizeletével nem volt panasza. A beteg korábbi anamnéziséből kiemelendő: prosztatatumor gyanúja (szövettani verifikáció nem történt), évtizedek óta fennálló, kezelt hypertonia, discushernia, bal szemen szürke hályog. A beteg vérnyomáscsökkentő gyógyszereket (urapidil, carvedilol, doxazosin, ramipril), valamint gyomorsavcsökkentőt (pantoprazol) szedett.

A beteg fizikális státusza eltérés nélkül mutatkozott, vérnyomása 190/100 Hgmm, spontán oxigénszaturációja 97\% volt. A beteg EKG-ján 70/min, sinusrhythmus látszódott, jobb-Tawara-szár-blokkal, szekunder ST-T eltérésekkel.

A mellkasi panasz ellátásának protokollja szerint a betegnél labor-, valamint mellkas-röntgenvizsgálat készült. A laborokból kiemelendő: pozitív D-dimer-érték $(2,7$ $\mu \mathrm{g} / \mathrm{ml}$ ), kissé beszúkült vesefunkció (eGFR: $46 \mathrm{ml} /$ min/1,73 $\mathrm{m}^{2}$ ), valamint negatív kardiális nekroenzimek (CK, CK-MB, high-sensitivity troponin I). A mellkasröntgenvizsgálat mindkét oldali lateralis sinusban folyadékot írt le, valamint tágabb pulmonalis fötörzseket véleményezett, egyebekben kóros eltérést nem talált.

A betegnél ezek alapján elsősorban pulmonalis embolia (PE) (pozitív D-dimer-érték, jobb-Tawara-szár-blokk, éles mellkasi fájdalom), valamint mellkasi aortadissectio (éles mellkasi fájdalom, vérnyomáskiugrás) lehetősége merült fel. A negatív kardiális nekroenzimek miatt ACS nem volt valószínúsíthető. A beteg Wells-score-ja 1 volt (a malignus alapbetegség gyanúja miatt), azonban a kli-

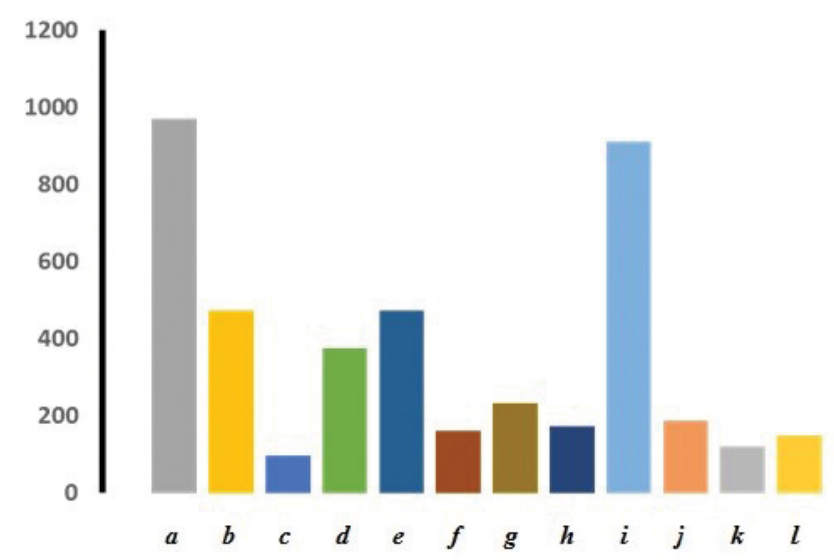

2. ábra

2014-2015-ben osztályunkon megforduló, mellkasi panasztól szenvedő betegek jellemző paraméterei

(a) Mellkasi panaszos betegek, akiknél ACS nem állt fenn (b) Pozitív kardiális rizikófaktor

(c) Diabetes mellitusban szenvedő betegek

(d) Magas vérnyomással diagnosztizált betegek

(e) Korábban kardiális megbetegedésben szenvedők

(f) Pszichiáter által is kezelt betegek

(g) Magnéziumtartalmú készítményt szedők

(b) Aszpirintartalmú készítményt használók

(i) Azok az esetek, amikor vérvétel történt

(j) Kontroll-labor is történt

(k) Azoknak az eseteknek a száma, amikor emelkedett CK-értéket mértünk

(l) Sürgősségi szívultrahang készült 
nikai kép alapján mégis a PE-t tartottuk a tüneteket magyarázó legvalószínúbb lehetôségnek.

Következő lépésben hidrálás, fájdalomcsillapítás, valamint antihipertenzív terápia után mellkasi CT-angiográfiás vizsgálatot végeztünk, amely tüdőembóliára utaló kontrasztkiesést nem ábrázolt a pulmonalis erekben. Aortadissectióra utaló jel szintén nem látszódott, azonban leírásra került a meszes aorta falán körkörösen rögzült thrombus. Végül meglepetésként a CT-lelet alapján a gyomor kétharmada a hátsó mediastinumban helyezkedett el. Ezek után sebészeti konzílium történt, ami osztályos felvételt és sürgős mütétet javasolt, kizáródott rekeszsérv alapos gyanúja miatt. A betegnél sürgősséggel laparoszkópos feltárás és rekeszsérv kizáródása miatt laparoszkópos Nissen-féle funduplikáció történt. Zavartalan posztoperatív szakot követően a beteg panaszmentesen távozott otthonába (1. ábra).

\section{Megbeszélés}

A tárgyalt esetben az egyébként nem ritka rekeszsérv heveny mellkasi panaszokat okozó formájának lehettünk tanúi. A rekeszsérv (hiatushernia) anatómiai alapja, hogy a rekeszizomnak vannak különböző Achilles-sarkai, méghozzá azok a pontok, ahol különböző anatómiai képletek lépnek át rajta. A rekeszsérv leggyakoribb helye a nyelőcső átlépésénél alakul ki. Ennek újabban négy formáját különítjük el [2].

l-es típusban vagy csuszamlásos (axiális) sérv esetén a cardia és a fundus, a peritoneumot magával húzva, a mellüregbe kerül: a gastrooesophagealis junctio gyengesége, a nyelőcső fokozott hosszanti összehúzódása, valamint a megnövekedett intraabdominalis nyomás következtében. Panaszokat nem okozó kismértékű csuszamlásos sérv 50 éves kor felett az emberek 50\%-ánál előfordul.

2-es típusban vagy paraoesophagealis sérv esetén a gastrooesophagealis junctio rögzített, a gyomor egy része a peritonealis sérvtömlővel együtt a nyelőcső mellé, a mellüregbe kerül. Lehet tünetmentes is, azonban gyakran tüneteket okoz.

3-as típusú hiatushernia esetén mindkét mechanizmus szerepet játszik, míg végül összenövések alakulnak ki a mediastinumba vándorolt hiatuszsák, valamint a pleura és a pericardium között.

A 4-es típus a hiatusherniák legsúlyosabb formája, az úgynevezett upside-down-stomach (mellkasi gyomor). Gyakran az egész gyomor a mellüregbe herniálódik, és hosszanti tengelye mentén rotálódik. Igen súlyos esetben a hasnyálmirigy, colon vagy lép is a mellkasba herniálódik [3].

A rekeszsérvek 85-90\%-a 1-es típusú, míg a maradék 10-15\% a 2-4-es típusok között oszlik meg. Az l-es típusú hiatus az esetek 90\%-ában panaszt nem okoz, a fennmaradó 10\%-ban refluxbetegség társul hozzá. A 2-4-es típusokhoz gyakran passzázszavar tünetei, dys- phagia, vérzés, fekélyképződés, fóleg, de nem kizárólag étkezés utáni mellkasi fájdalom, hányinger, böfögés társul. Súlyos esetben a sérv incarcerálódhat, gyomorvolvulus, perforáció következhet be, amely heveny életveszélyes állapot lehet [4].

A rekeszsérvek azonban nemcsak utánozni tudnak cardiovascularis betegségeket, hanem azok kiváltó okaiként is szerepelhetnek. A mellüregbe herniálódott gyomor nyomást gyakorolhat a szív üregeire vagy a mediastinumban elhelyezkedő nagyerekre, így kiválthatnak anginaszerü mellkasi fájdalmat, syncopét, szívritmuszavarokat, gastropericardialis fistulát, pericardialis folyadékgyülemet, légzési elégtelenséget, fulladást, súlyos esetben szívelégtelenséget, tüdőödémát. A sürgősségi orvos dolgát még inkább megnehezíti, hogy e folyamatok által a hiatushernia olyan EKG-eltéréseket okozhat, mint például T-hullám-inverzió vagy ST-T eltérések, amik tévesen ACS gyanúját vethetik fel. Azonban a kialakult EKG-eltérések a rekeszsérv mütéti korrekciója után rendszerint nyomtalanul eltünnek [5].

A diagnózis sokszor egyszerú mellkasi röntgenvizsgálattal felállítható, azonban báriumpépes nyelés-röntgenvizsgálat vagy gasztroszkópia megerősíti gyanúnkat. A rekeszsérv kezelése főként a tüneteket okozó reflux kezelését jelenti, azonban főként a 2-4-es típusokban a sebészi kezelés lehetősége is megfontolandó. Kizáródás esetén természetesen a sürgős mútét életmentő megoldás [6].

\section{Mellkasi fájdalom elófordulása osztályunkon}

Osztályunk felmérést készített a 2014-2015-ben megjelent mellkasi panaszos betegek körében (2. ábra). A vizsgált időszakban 980 beteg jelentkezett mellkasi fájdalom miatt. Mindösszesen 8 esetben diagnosztizáltunk ACS-t, amely annak köszönhető, hogy ezeknek a betegeknek nagy része közvetlenül a hemodinamikai laborba érkezik. A maradék (a) 972 beteg adatait dolgoztuk fel (2. ábra). Átlagéletkoruk 51,7 év volt. Összesen (b) 472 betegnek voltak pozitív kardiális rizikófaktorai (48\%), (c) 96-an (9\%) szenvedtek diabetes mellitustól, míg (d) 376 beteget $(38 \%)$ magas vérnyomással diagnosztizáltak. Érdekes, hogy éppen (e) 472 betegnél észleltek korábban kardiális megbetegedést (angina pectoris, ischaemiás szívbetegség stb.). Összesen (f) 160 beteget kezelt korábban pszichiáter (24\%), ezek közül 36-an szenvedtek major pszichiátriai megbetegedésben (depresszió, bipoláris zavar, szkizofrénia). (g) 232 beteg szedett korábban magnéziumtartalmú (23\%), míg (b) 172 aszpirintartalmú készítményt, ami azért meglepően kevés, mert 472 beteget korábban szívbetegséggel diagnosztizáltak. Osztályunkról való elbocsátásakor 100 betegnek javasoltuk aszpirintartalmú készítmény szedését. A vizsgált 972 betegből (i) 912-nek volt vérvétele (93\%), (j) 188 esetben kontroll-labor is készült $(20 \%)$, döntően 6 óra múlva. Összesen (k) 120 esetben mutattunk ki emelkedett CK- 
1. táblázat |A mellkasi fájdalom differenciáldiagnosztikája

\begin{tabular}{|c|c|c|}
\hline Kardiális eredet & Pulmonalis eredet & $\begin{array}{l}\text { Mediastinum } \\
\text { betegségei }\end{array}$ \\
\hline $\begin{array}{l}\text { ISZB (stabil, instabil } \\
\text { angina pectoris, } \\
\text { AMI) }\end{array}$ & Tüdőembólia & $\begin{array}{l}\text { Mediastinalis } \\
\text { térfoglalás }\end{array}$ \\
\hline Hipertenzív krízis & Pleuritis & Mediastinitis \\
\hline $\begin{array}{l}\text { Ritmuszavarok } \\
\text { (pitvarfibrilláció) }\end{array}$ & $\begin{array}{l}\text { Pneumonia, } \\
\text { bronchitis }\end{array}$ & Aortadissectio \\
\hline Billentyúbetegségek & Tbc & $\begin{array}{l}\text { Aortaneurysma- } \\
\text { ruptura }\end{array}$ \\
\hline Myocarditis & Tüdődaganat & Sarcoidosis \\
\hline Pericarditis & Ptx & \\
\hline Mellkasfali betegségek & $\begin{array}{l}\text { Gastrointestinum } \\
\text { betegségei }\end{array}$ & $\begin{array}{l}\text { Funkcionális } \\
\text { mellkasi fájdalom }\end{array}$ \\
\hline Herpes-zooster & Reflux & Pánikszindróma \\
\hline Tietze-szindróma & $\begin{array}{l}\text { Boorhaave- } \\
\text { szindróma }\end{array}$ & Szorongás \\
\hline Fibromyalgia & Hiatushernia & Hipochondria \\
\hline Bornholm-betegség & $\begin{array}{l}\text { Nyelőcső-motilitás } \\
\text { zavarai }\end{array}$ & Szomatizáció \\
\hline $\begin{array}{l}\text { Mellkasfali } \\
\text { deformitások } \\
\text { (tölcsérmellkas) }\end{array}$ & $\begin{array}{l}\text { Nyelőcső gyulladása, } \\
\text { daganata }\end{array}$ & Da Costa-szindróma \\
\hline Radiculopathia & $\begin{array}{l}\text { Funkcionális } \\
\text { dyspepsia }\end{array}$ & Hiperventiláció \\
\hline Emlő betegségei & $\begin{array}{l}\text { Mellkasba sugárzó } \\
\text { hasfájdalom } \\
\text { (pancreatitis) }\end{array}$ & \\
\hline \multicolumn{3}{|l|}{ Osteoarthritis } \\
\hline \multicolumn{3}{|l|}{$\begin{array}{l}\text { „Thoracic outlet” } \\
\text { szindróma }\end{array}$} \\
\hline $\begin{array}{l}\text { Traumás eredetű } \\
\text { eltérések }\end{array}$ & & \\
\hline
\end{tabular}

értéket, azonban CK-MB-t, illetve troponint egy esetben sem. (l) 148 beteg esetében készült sürgősségi szívultrahangvizsgálat (15\%). A mellkasi panaszos betegek átlagosan 4 órát töltöttek el osztályunkon.

\section{Következtetések}

A fent említett esetben a beteg mellkasi fájdalmát hatalmas rekeszsérv okozta. A mellkasi fájdalmak kiváltó okaként azonban számos kórképet különíthetünk el. A mellkasi fájdalom jelentősége nem elbagatellizálható, hiszen a fejlett országokban a halálozási statisztikák vezető he- lyén a cardiovascularis betegségek állnak. A magas morbiditási, valamint mortalitási mutatókért fooként a koszorúér-betegségek különböző megjelenési formái tehetők felelőssé. De nem lehet szem elől téveszteni, hogy az ACS-n kívül számos más, akár az életet veszélyeztető kórkép állhat a mellkasi fájdalom hátterében (1. táblázat). Elsősorban, rutinszerüen, a mellkasi fájdalom hátterében álló gyakori okokat kell kizárnunk. Amennyiben a beteg kórelőzményében szerepel hiatushernia, úgy felmerül a sürgős hasi és mellkasi kontrasztos CT-vizsgálat elvégzése elsődleges diagnosztikus képalkotó vizsgálatként. A sürgősségi osztályokon dolgozó orvosok mindennapjait nehezíti, hogy a mellkasi fájdalmat okozó kórképek „ezer arca” tárul eléjük, így fontos a multidiszciplináris szemlélet, a társszakmákkal való szoros együttmúködés [7].

Anyagi támogatás: A szerzők anyagi támogatásban nem részesültek.

Szerzôi munkamegosztás: B. B., Sz. I.: A kézirat megírása. K. I., H. Zs., S. O., P.-Sz. J.: Adatok szolgáltatása. A cikk végleges változatát valamennyi szerző elolvasta és jóváhagyta.

Érdekeltségek: A szerzőknek nincsenek érdekeltségeik.

\section{Irodalom}

[1] Kontos, M. C., Diercks, D. B., Kirk, J. D.: Emergency department and office-based evaluation of patients with chest pain. Mayo Clin. Proc., 2010, 85(3), 284-299.

[2] Roman, S., Kabrilas, P. J.: The diagnosis and management of hiatus hernia. BMJ, 2014, 23, 349, g6154.

[3] Kahrilas, P. J., Kim, H. C., Pandolfino, J. E.: Approaches to the diagnosis and grading of hiatal hernia. Best Pract. Res. Clin. Gastroenterol., 2008, 22(4), 601-616.

[4] Hyun, J. J., Bak, Y. T.: Clinical significance of hiatal hernia. Gut Liver, 2011, 5(3), 267-277.

[5] Vanerio, G.: Syncope caused by huge hiatal hernia. Case Rep. Cardiol., 2011, 2011, 560734.

[6] Sabin, C., Akin, F., Cullu, N., et al.: A large intra-abdominal hiatal hernia as a rare cause of dyspnea. Case Rep. Cardiol., 2015, 2015, Article ID 546395.

[7] Coss-Adame, E., Erdogan, A., Rao, S. S.: Treatment of esophageal (non-cardiac) chest pain: an expert review. Clin. Gastroenterol. Hepatol., 2014, 12(8), 1224-1245.

(Szabó István dr., Kecskemét, Nyíri út 38., 6000 e-mail: szaboi@kmk.hu) 